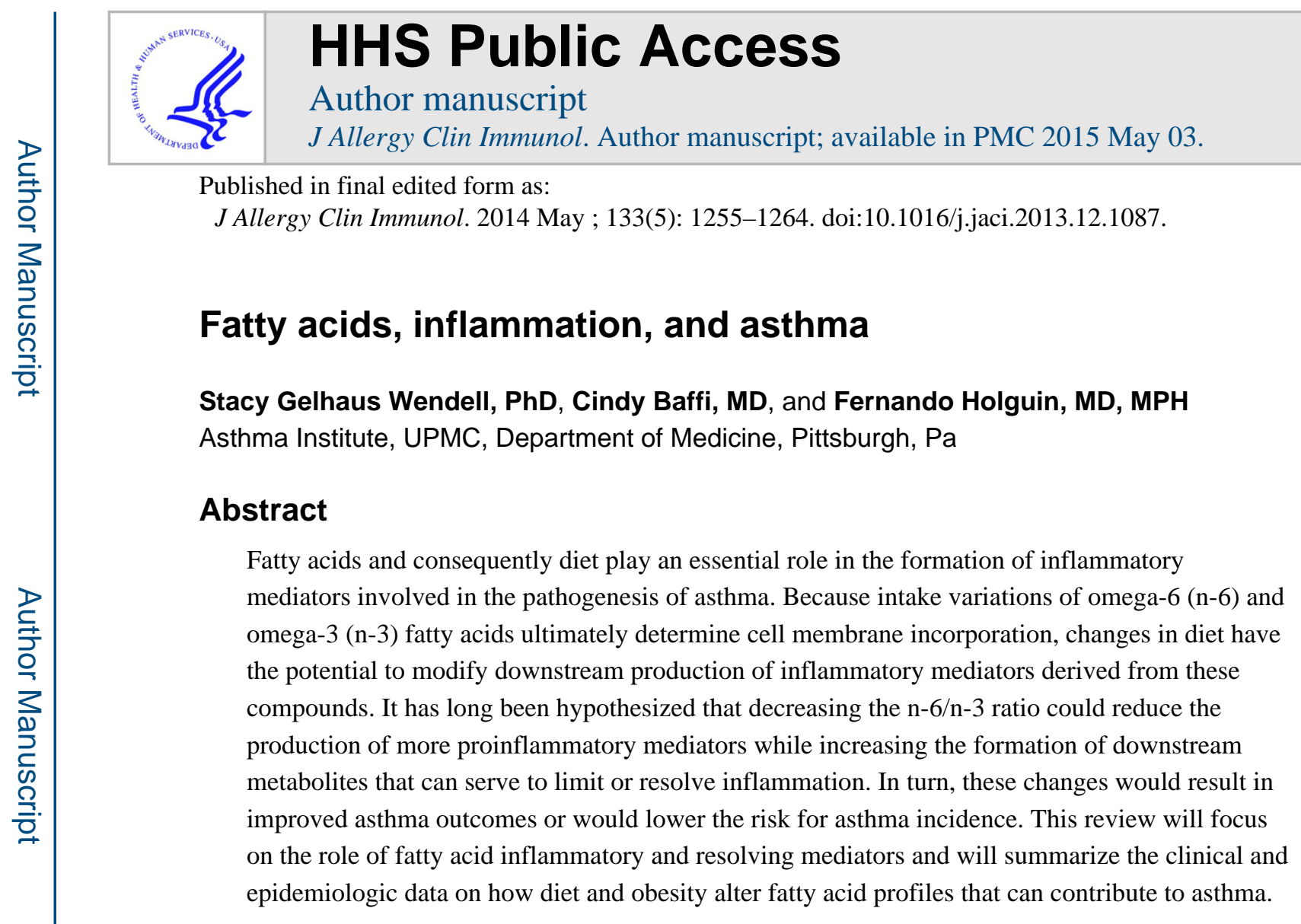

\title{
Keywords
}

Asthma; diet; obesity; fatty acids; n-6; n-3; inflammation; resolution

Chronic airway inflammation is coordinated by a complex web of inflammatory mediators, including interleukins, adhesion molecules, inflammatory enzymes, and lipid mediators. Rigorous study in the area of lipid mediators has revealed that these mediators are produced at specific points during the processes of inflammation and resolution. Some lipid mediators promote inflammation, whereas others are made at later stages in the process and promote a return to cellular homeostasis in the resolution phase. When transition to the resolving phase from an inflammatory response to an acute injury does not occur or a state of chronic inflammation manifests, the system is overwhelmed, and negative physiologic consequences occur. Such is the case in asthma, a disease mediated by chronic airway inflammation leading to bronchoconstriction and, potentially, airway remodeling.

Most of the lipid mediators that regulate inflammation are metabolites derived from omega-6 (n-6) or omega-3 (n-3) fatty acids, including arachidonic acid (AA; 20:4n-6), linoleic acid (LA; 18:2n-6), eicosapentaenoic acid (EPA; 20:5n-3), and docosahexaenoic acid (DHA; 22:6n-3; Fig 1). Through enzymatic oxidation by COX, lipoxygenase (LO), cytochrome P450 (CYP) enzymes, or reactive oxygen species, oxygenated metabolites are

(C) 2014 American Academy of Allergy, Asthma \& Immunology

Corresponding author: Fernando Holguin, MD, MPH, Asthma Institute, UPMC, Department of Medicine, MONF NW628, Pittsburgh, PA 15213. feh9@pitt.edu. Or: holguinf@upmc.edu.

Disclosure of potential conflict of interest: The authors declare that they have no relevant conflicts of interest. 
formed, many of which possess biological actions. n- 6 fatty acids are generally described as proinflammatory, and n-3 fatty acids are generally described as anti-inflammatory. In general, this is true; however, it has been realized that although a fatty acid mediator might be proinflammatory in one disease or tissue, it can be anti-inflammatory in another, as is the case for the AA-derived prostaglandin ( $\mathrm{PG}) \mathrm{E}_{2}$.

The main AA-derived mediators of inflammation in asthma are PGs and cysteinyl leukotrienes (CysLTs). ${ }^{1,2}$ There are many other eicosanoids that have been implicated; however, their roles remain somewhat controversial compared with PGs and leukotrienes (LTs). Therefore this review will focus only on PGs and LTs as inflammatory mediators. Proresolving fatty acids are formed in response to an inflammatory event and accelerate a return to cellular homeostasis. Most of these are n-3-derived metabolites and include resolvins, protectins, and maresins. The one exception is the lipoxin family, which is derived from AA. ${ }^{3,4}$ The formation of these proresolving fatty acids requires the enzymatic activity of 5- and 15-LO, typically from 2 different cell types. ${ }^{4}$ A third category of lipid mediators are the anti-inflammatory electrophilic fatty acids. This group is derived from both $n-6$ and $\mathrm{n}-3$ fatty acids and include metabolites that contain an $\alpha, \beta$-unsaturated carbonyl, epoxide, or the addition of a nitro group on an alkene. ${ }^{5}$ A plethora of recent studies have shown that they have pleiotropic signaling actions that mediate inflammation by upregulating antiinflammatory pathways and downregulating proinflammatory signaling. Lastly, the implications of fatty acid dietary intake on asthma will be discussed.

\section{MEDIATORS OF INFLAMMATION}

\section{PGs and CysLTs}

PGs and CysLTs are metabolites of AA.AA is cleaved from the $s n-2$ position of phospholipids by phospholipase $\mathrm{A}_{2}$. In the case of PGs, AA can be a substrate for either of the COX isoforms COX-1, which is constitutively expressed, or COX-2, which is upregulated in inflammation and primarily responsible for PG formation in asthmatic patients. AA is converted to $\mathrm{PGG}_{2}$ in one active site and reduced by the endoperoxide active site to $\mathrm{PGH}_{2}$. Specific synthase enzymes use $\mathrm{PGH}_{2}$ as a substrate, and the resulting products are thromboxane $\mathrm{A}_{2}, \mathrm{PGI}_{2}, \mathrm{PGF}_{2 a}, \mathrm{PGD}_{2}$, and $\mathrm{PGE}_{2}$. $\mathrm{PGE}_{2}$ is the most abundant $\mathrm{PG}$ in the human body and a major metabolite in the lower respiratory tract. ${ }^{6,7} \mathrm{PGE}_{2}$ has been labeled as proinflammatory because of its multiplicity of effects on the immune system, but in the respiratory system $\mathrm{PGE}_{2}$ is unique in that it has beneficial effects. Cell types that contribute to its production include airway epithelium and smooth muscle, fibroblasts, endothelial cells, and alveolar macrophages. ${ }^{8} \mathrm{PGE}_{2}$ protects against bronchoconstriction, increases relaxation of airway smooth muscle, and has been shown to inhibit the release of mast cell mediators and the recruitment of inflammatory cells. ${ }^{6}$ Many, if not all, of these effects are mediated through one of $4 \mathrm{PGE}_{2}$ prostanoid G protein-coupled receptors (GPCRs; ie, EP1EP4). ${ }^{7}$

Although $\mathrm{PGE}_{2}$ has been exemplified as an anti-inflammatory $\mathrm{PG}, \mathrm{PGD}_{2}$ has been shown to be proinflammatory, despite the fact that they are isomers in which the hydroxyl group and keto group are on opposite sides of the prostanoid ring. Active mast cells generate CysLTs and $\mathrm{PGD}_{2} . \mathrm{PGD}_{2}$ is mainly produced from mast cells that contain a hematopoietic $\mathrm{PGD}_{2}$ 
synthase, and it has been shown that there is a positive correlation of $\mathrm{PGD}_{2}$ concentration to asthma severity in bronchoalveolar lavage fluid. ${ }^{8} \mathrm{PGD}_{2}$ acts through the thromboxane GPCR, the $\mathrm{PGD}_{2}$ receptor 1 (DP1), and the chemoattractant receptor-homologous molecule expressed on $\mathrm{T}_{\mathrm{H}} 2$ lymphocytes (CRTH2/DP2). ${ }^{8}$ The thromboxane GPCR promotes smooth muscle constriction that likely contributes to bronchoconstriction in asthmatic patients. CRTH2 activation on $\mathrm{T}_{\mathrm{H}} 2$ lymphocytes, eosinophils, and basophils results in enhanced chemotaxis and activation. $\mathrm{CRTH} 2$ receptor binding also induces cytokine production that might play a role in IgE activation by mast cells. ${ }^{8}$

\section{CysLTs}

CysLTs are also key mediators of asthma. LTs are derived from AA and synthesized through the 5-LO pathway in conjunction with 5-LO activating protein to catalyze the oxidation of AA to $\mathrm{LTA}_{4}$. The epoxide ring of $\mathrm{LTA}_{4}$ is opened by $\mathrm{LTA}_{4}$ hydrolase to form $\mathrm{LTB}_{4}$ or it is conjugated to glutathione by $\mathrm{LTC}_{4}$ synthase to form $\mathrm{LTC}_{4} . \mathrm{LTC}_{4}$ is transported out of the cell by multidrug resistance- associated protein $1 . \mathrm{LTC}_{4}$ is then subjected to extracellular metabolism to form $\mathrm{LTD}_{4}$ (loss of glutamine) and $\mathrm{LTE}_{4}$ (loss of glycine). ${ }^{1}$ These 3 LTs, $\mathrm{LTC}_{4}, \mathrm{LTD}_{4}$, and $\mathrm{LTE}_{4}$, comprise the CysLTs. Eosinophils and mast cells are primarily responsible for the synthesis of CysLTs in the context of asthma. ${ }^{1,2}$ Bronchoconstriction, the initiation of proinflammatory cytokine production, and airway remodeling have all been attributed to CysLTs. Additionally, CysLTs have been implicated in the trafficking and degranulation of eosinophils in the lungs, increased microvascular permeability leading to pulmonary edema, and increased mucus secretion. ${ }^{1,9}$ Unfortunately, only $50 \%$ of asthmatic patients show clinical responses to CysLT receptor agonists. ${ }^{9}$

\section{PRORESOLVING MEDIATORS}

A class of inflammation-resolving fatty acids derived from AA, EPA, and DHA exist that are dihydroxy or trihydroxy in nature. The AA-derived lipoxins and the EPA- and DHAderived resolvins, protectins, and maresins are produced by dualenzyme reactions during acute inflammation and are proposed to mediate resolution. ${ }^{10}$ These mediators block neutrophil recruitment, promote infiltration and activation of monocytes, and induce phagocytosis and lymphatic clearance of apoptotic neutrophils by activated macrophages. ${ }^{10}$ These polyhydroxylated species require transcellular biosynthesis, the sequential actions of LOs from neighboring cells (ie, 5-LO/12-LO or 15-LO/5-LO), or they can be formed by a combination of COX-2 and cytochrome P450 or LO. ${ }^{10,11}$ The EPA-derived resolvin E1 was shown to dampen airway inflammation and airway hyperresponsiveness (AHR) in a mouse model of asthma. ${ }^{12}$ Mice administered resolvin E1 had lower eosinophil and lymphocyte recruitment, lower IL-13 and OVA-specific IgE levels, and a lower response to methacholine challenge compared with controls. ${ }^{12}$ A review by Uddin and Levy ${ }^{4}$ in 2011 summarizes the proresolving role of resolvins in pulmonary inflammation. In a study comparing patients with aspirin-intolerant asthma (AIA) with those with aspirin-tolerant asthma, Sanak et $\mathrm{al}^{13}$ reported a reduced generation of lipoxin $\mathrm{A}_{4}\left(\mathrm{LXA}_{4}\right)$ and aspirintriggered $\mathrm{LXA}_{4}$ in patients with AIA. ${ }^{13}$ However, Celik et al ${ }^{14}$ found similar levels of $\mathrm{LXA}_{4}$ in both patients with AIA and those with aspirin-tolerant asthma. This difference might be attributed to a misclassification of asthmatic patients because $\mathrm{LXA}_{4}$ levels are consistently 
lower in patients with severe asthma, regardless of aspirin tolerance. ${ }^{7}$ The actions of these proresolving fatty acids are mediated by their binding to specific GPCRs, including CMKLR1, BLT1, ALX/FPR2, and GPR32. ${ }^{4}$ Additionally, these proresolving species have also been shown to trigger the expression of anti-inflammatory mediators, such as TGF- $\beta$ and IL-10. ${ }^{4}$ Fat- 1 mice ${ }^{15}$ express a Caenorhabiditis elegans desaturase that converts n- 6 to $\mathrm{n}-3$ fatty acids, thus increasing endogenous anti-inflammatory and proresolving $\mathrm{n}-3$ metabolites. These mice additionally showed a decrease in levels of AA-derived eicosanoids, decreased allergic airway inflammation, and decreased response to methacholine challenge compared with those seen in control mice that were OVA challenged. ${ }^{15}$

\section{ELECTROPHILIC FATTY ACIDS}

Polyunsaturated fatty acid (PUFA) oxidation to an $\alpha, \beta$-unsaturated ketone or epoxide and the addition of nitrogen dioxide $\left({ }^{\circ} \mathrm{NO}_{2}\right)$ to an alkene result in the formation of electrophilic fatty acid species. Many of these electrophilic fatty acids, such as 17-oxo-DHA, 15 deoxy ${ }^{\Delta 12,14}-\mathrm{PGJ}_{2}$, and nitro-oleic acid $\left(\mathrm{NO}_{2}-\mathrm{OA}\right)$, have been structurally characterized and described as downstream metabolites of n-3 and n-6 PUFAs, but not all have been defined with regard to their biological function, despite their abundance. 5,16

Electrophilic fatty acids function through the posttranslational modification of proteins and transcription factors. Multiple classes of electrophilic signaling molecules are expected to have unique patterns of downstream signaling. Electrophilic fatty acids will adduct susceptible, nucleophilic amino acid residues, such as cysteine and histidine. This adduction induces alterations in protein structure, function, and subcellular distribution. ${ }^{17}$ The targets for electrophilic fatty acid modification are thus diverse, yielding pleiotropic and sometimes reversible effects on an array of key signaling pathways. The oxo-DHA and oxo-EPA species inhibit proinflammatory cytokine and ${ }^{\circ} \mathrm{NO}$ production and activate Nrf2-dependent gene expression. ${ }^{16}$ Although dependent on concentration, target specificity, cell type, metabolism, and reversibility, ${ }^{18,19}$ many of these effects provide beneficial outcomes in the context of inflammation and play a potential role in asthma. ${ }^{20}$ Aside from Nrf2, other key target proteins for electrophilic fatty acids include the peroxisome proliferator activator receptor $\gamma(\mathrm{PPAR} \gamma)$ and nuclear factor $\kappa \mathrm{B} .{ }^{5}$ Importantly, the endogenous production of these molecules is often a result of pro-oxidative and stress conditions, thus providing a rheostat mechanism for resolving the inflammatory environment.

A recent article by Reddy et $\mathrm{al}^{21}$ demonstrated that $10-\mathrm{NO}_{2}$-OA decreased airway inflammation and AHR after methacholine challenge to the same extent as fluticasone in a mouse model using ovalbumin as the challenge. In addition, $10-\mathrm{NO}_{2}-\mathrm{OA}$, but not fluticasone, stimulates neutrophil apoptosis and phagocytosis. This was attributed to an increase in PPAR $\gamma$ activity. ${ }^{21}$ In vitro studies showed that $10-\mathrm{NO}_{2}-\mathrm{OA}$ significantly upregulated CD36 expression by alveolar macrophages. This was in contrast to fluticasone treatment, which abolished CD36 expression. ${ }^{21}$ 


\section{DIET AND ASTHMA}

It has been hypothesized that variations in asthma prevalence across populations and the increase in asthma burden seen in westernized societies over past decades might be related to a combination of a progressively higher intake of $n-6$ fatty acids, such as LA, which is found in margarine and vegetable oils, and a lower intake of $n-3$, which is found in marine oils. ${ }^{22}$ This concept is largely supported by epidemiologic studies showing that populations with higher n-6 fatty acid consumption have greater asthma prevalence in contrast to those consuming average higher $\mathrm{n}-3$ fatty acid diets, such as the Eskimos. ${ }^{23}$ Given that $\mathrm{n}-3$ fatty acids produces eicosanoids that are less proinflammatory ( $\mathrm{PGE}_{3}$ and $\mathrm{LTB}_{5}$ series) than those derived from $\mathrm{n}-6$ fatty acids ( $\mathrm{PGD}_{2}$ and $\mathrm{LTB}_{4}$ series) and because downstream metabolites of $\mathrm{n}-3$ fatty acids have the potential to resolve inflammation, the hypothesis that $\mathrm{n}-3$ fatty acid intake could improve asthma by reducing inflammation seems biologically plausible. However, the lack of consistency across observational studies and clinical trials (Table I) ${ }^{24-39}$ certainly raises the possibility that $n-3$ fatty acids might not be as universally effective as originally considered. Therefore it is possible that these compounds are only effective in select asthma phenotypes.

Observational studies have not consistently shown in children or adults that increased n-3 fatty acid intake is associated with improved $\mathrm{FEV}_{1}$, respiratory symptoms, or asthma control. Similarly, some studies have shown that lower n-3 fatty acid levels or decreased n-3/n-6 ratios are protective for asthma. Paradoxically, increased n-3 intake was related to higher wheeze prevalence (Table I). In addition to the residual confounders from many potential biases associated with n-3 fatty acid intake, the lack of consistency in results across observational studies might relate to many ways that fatty acid consumption is estimated; although some studies use food frequency questionnaires, others rely on plasma or cell membrane levels (Table I).

Several randomized clinical trials have been conducted to date for the treatment of asthma (Table II). ${ }^{40-50}$ As with observational studies, the use of diverse clinical end points for study outcomes, in addition to different combinations of n-3 fatty acid concentration and duration, makes it difficult to appreciate whether this intervention is useful. However, pooled estimates derived from a Cochrane meta-analysis of 9 randomized clinical trials did not show improvements in clinical outcomes, including bronchial hyperresponsiveness. ${ }^{51}$ Therefore the study authors found insufficient evidence to recommend the use of n-3 fatty acid products to improve the health of asthmatic patients. Considering that asthma is a complex syndrome comprised of diseases with different clinical phenotypes, select asthmatic patients could benefit more from taking n-3 fatty acids or, alternatively, be harmed more by being exposed to higher concentrations of $n-6$ fatty acids. Among atopic asthmatic patients, $n-3$ fatty acid supplementation has been shown to reduce exhaled nitric oxide levels and sputum eosinophil counts in asthmatic patients pre-exposed to sensitized allergens; however, these results have not been widely replicated. ${ }^{40}$ Two well-conducted randomized studies have shown that $\mathrm{n}-3$ fatty acid supplementation significantly reduces the exerciseinduced $\mathrm{FEV}_{1}$ decrease and reduces use of short-acting $\beta$-agonists, ${ }^{40-42,52}$ although a similar intervention was not useful among patients with mild-to-moderate asthma exercising with less intensity under ambient conditions. ${ }^{53}$ 
There have been a limited number of projects evaluating whether $n-3$ fatty acid exposure in utero could reduce the incidence of atopy and asthma in offspring. Although the majority show some degree of protection, this has not been a consistent result across all studies. Protection is thought to occur through a mechanism involving n-3 fatty acid-mediated reductions in $\mathrm{PGE}_{2}$ levels, which can subsequently decrease $\mathrm{T}_{\mathrm{H}}$ 2-related cytokine and $\mathrm{IgE}$ levels. ${ }^{43,54,55}$

Although fish oil supplementation does not result in improved asthma control, it might be that management of overall caloric intake of saturated fats is more important. One key feature of the western diet is a chronic metabolic surplus that is low in antioxidants but high in saturated fats, leading to storage of these surplus fats and eventually obesity. It is not disputed that obesity and asthma are linked; however, this relationship has not been well defined. Obesity can be differentiated by its low-grade chronic inflammatory state and already altered immune system because of an increase in proinflammatory adipokine and leptin/adiponectin levels. ${ }^{56}$ This proinflammatory state found in obesity might be a critical player in the role of lipid mediators in asthmatic patients. A very telling study conducted by de Vries and Howie ${ }^{57}$ showed that mice fed a diet high in saturated fat and allergen challenged before having an obese phenotype (between 6-8 weeks) displayed decreased proinflammatory cytokine production by lung draining lymph node cells and decreased eotaxin and lung eosinophilia compared with control mice on an $11 \%$ fat diet. Compared with a low-fat diet, asthmatic patients randomized to a high-fat diet showed acute increased airway neutrophilia and Toll-like receptor 4 mRNA expression and reductions in FEV $F_{1}$ and forced vital capacity. These studies strongly suggest that a higher fat intake can lead to airway inflammatory and functional changes, which could worsen asthma symptoms.

\section{CONJUGATED LINOLEIC ACID: THE BENEFICIAL n-6 FATTY ACID}

Conjugated linoleic acid (cLA) has been touted for its favorable health implications, including its anticancer and anti-inflammatory properties and its association with reduced risk of cardiovascular events. ${ }^{58-60}$ This $\mathrm{n}-6$ fatty acid is synthesized in vivo by rumen bacteria from LA and might also be created during the heat processing of animal-derived foods, including milk and meat. Meat contributes approximately $25 \%$ to $30 \%$ of cLA in a Western diet, with the remainder from dairy. Although found in meat and dairy products, nonruminants and human subjects produce cLA from the trans-isomer of OA (vaccenic acid). This cLA formation is mediated by the entero-salivary microbiome through bacterial $\Delta^{9}$-desaturase activity. ${ }^{60}$ Over the years, normal dietary consumption of cLA has decreased in the western diet because of changes in our consumption, some of which reflect a hearthealthy diet.

cLA was first recognized for its metabolic effects on obesity, body composition, and insulin insensitivity. ${ }^{26}$ The predominant isomer of cLA in milk and meat is cis-9, trans-11-LA. This is in contrast to the commercial preparation, which is typically derived from sunflower oil, in which proportions of the 2 main isomers (cis-9, trans-11 and trans-10, cis-12) are equal. ${ }^{26}$ Although specific effects have been attributed to individual isomers, many animal and human studies have used a combination of the 2 main isomers. In a study by MacRedmond et al, ${ }^{61}$ investigators asked whether cLA would be efficacious as a dietary 
supplement for overweight patients with mild asthma. In this randomized, double-blind, placebo-controlled study subjects were given $4.5 \mathrm{~g} / \mathrm{d}$ cLA or placebo for 12 weeks. The average body mass index of the group was $27.9 \mathrm{~kg} / \mathrm{m}^{2}$. Measurements at week 12 compared with initial testing showed that the group receiving cLA had significant improvements in AHR, as measured based on the results of methacholine challenge $\left(\mathrm{PC}_{20}\right)$, and a significant decrease in body mass index with an associated reduction in the leptin/adiponectin ratio. Subjects also reported an increased tolerance for severe exercise. However, there were no differences in $\mathrm{FEV}_{1}$, systemic cytokine levels, or induced sputum cell counts. Much like n-3 PUFAs compete with n-6 PUFAs as substrates for enzymatic oxidation, cLA might compete with LA as a substrate for desaturases and elongases, resulting in an overall reduction in AA formation. cLA might also reduce eicosanoid formation through the transcriptional regulation of COX and LO and could mediate inflammation through PPAR $\gamma \cdot{ }^{26}$ All of these mechanisms and effects on body composition would benefit asthmatic patients. ${ }^{62}$

\section{CONCLUSIONS}

Fatty acids play an essential role in the development and resolution of inflammatory pathways relevant to the pathophysiology of asthma. Although dietary interventions have been largely disappointing, there is ongoing interest to determine whether specific endogenous fatty acids can be used as therapeutic agents to resolve airway inflammation in asthmatic patients and, perhaps more importantly, to determine which type of asthmatic phenotype would gain the greatest benefit.

\section{Abbreviations used}
AA
Arachidonic acid
AHR
Airway hyperresponsiveness
AIA
Aspirin-intolerant asthma
cLA
Conjugated linoleic acid
CRTH2/DP2
Chemoattractant receptor-homologous molecule expressed on $\mathrm{T}_{\mathrm{H}} 2$ lymphocytes

$\begin{array}{ll}\text { CysLT } & \text { Cysteinyl leukotriene } \\ \text { DHA } & \text { Docosahexaenoic acid } \\ \text { EPA } & \text { Eicosapentaenoic acid } \\ \text { GPCR } & \text { G protein-coupled receptor }\end{array}$
LA Linoleic acid
LO Lipoxygenase
LT Leukotriene
$\mathbf{L X A}_{4} \quad$ Lipoxin $\mathrm{A}_{4}$
n-3 Omega-3 
n-6 Omega-6

OA Oleic acid

PG Prostaglandin

PPAR $\gamma \quad$ Peroxisome proliferator activator receptor $\gamma$

PUFA Polyunsaturated fatty acid

\section{REFERENCES}

1. Funk CD. Prostaglandins and leukotrienes: advances in eicosanoid biology. Science. 2001; 294:1871-1875. [PubMed: 11729303]

2. Wenzel SE. Arachidonic acid metabolites: mediators of inflammation in asthma. Pharmacotherapy. 1997; 17(Suppl):3S-12S. [PubMed: 9017783]

3. Levy BD. Resolvin D1 and resolvin E1 promote the resolution of allergic airway inflammation via shared and distinct molecular counter-regulatory pathways. Front Immunol. 2012; 3:390. [PubMed: 23293638]

4. Uddin M, Levy BD. Resolvins: natural agonists for resolution of pulmonary inflammation. Prog Lipid Res. 2011; 50:75-88. [PubMed: 20887750]

5. Schopfer F, Cipollina C, Freeman BA. Formation and signaling actions of electrophilic lipids. Chem Rev. 2011; 111:5997-6021. [PubMed: 21928855]

6. Sastre B, del Pozo V. Role of PGE2 in asthma and nonasthmatic eosinophilic bronchitis. Mediators Inflamm. 2012; 2012:645383. [PubMed: 22529528]

7. Velazquez JR, Teran LM. Aspirin-intolerant asthma: a comprehensive review of biomarkers and pathophysiology. Clin Rev Allergy Immunol. 2013; 45:75-86. [PubMed: 23184151]

8. Fajt ML, Gelhaus SL, Freeman B, Uvalle CE, Trudeau JB, Holguin F, et al. Prostaglandin D(2) pathway upregulation: relation to asthma severity, control, and TH2 inflammation. J Allergy Clin Immunol. 2013; 131:1504-1512. [PubMed: 23506843]

9. Misso, NL.; Thompson, PJ. Prostaglandins and leukotrienes: mediators of inflammation and asthma. Enfield (NH): Science Publishers; 2012.

10. Serhan CN, Petasis NA. Resolvins and protectins in inflammation resolution. Chem Rev. 2011; 111:5922-5943. [PubMed: 21766791]

11. Serhan CN, Fredman G, Yang R, Karamnov S, Belayev LS, Bazan NG, et al. Novel proresolving aspirin-triggered DHA pathway. Chem Biol. 2011; 18:976-987. [PubMed: 21867913]

12. Aoki H, Hisada T, Ishizuka T, Utsugi M, Kawata T, Shimizu Y, et al. Resolvin E1 dampens airway inflammation and hyperresponsiveness in a murine model of asthma. Biochem Biophys Res Commun. 2008; 367:509-515. [PubMed: 18190790]

13. Sanak M, Levy BD, Clish CB, Chiang N, Gronert K, Mastalerz L, et al. Aspirin-tolerant asthmatics generate more lipoxins than aspirin-intolerant asthmatics. Eur Respir J. 2000; 16:44-49. [PubMed: 10933083]

14. Celik GE, Erkekol FO, Misirligil Z, Melli M. Lipoxin A4 levels in asthma: relation with disease severity and aspirin sensitivity. Clin Exp Allergy. 2007; 37:1494-1501. [PubMed: 17883729]

15. Bilal S, Haworth O, Wu L, Weylandt KH, Levy BD, Kang JX. Fat-1 transgenic mice with elevated omega-3 fatty acids are protected from allergic airway responses. Biochim Biophys Acta. 2011; 1812:1164-1169. [PubMed: 21616147]

16. Groeger AL, Cipollina C, Cole MP, Woodcock SR, Bonacci G, Rudolph TK, et al. Cyclooxygenase- 2 generates anti-inflammatory mediators from omega-3 fatty acids. Nat Chem Biol. 2010; 6:433-441. [PubMed: 20436486]

17. Batthyany C, Schopfer FJ, Baker PR, Duran R, Baker LM, Huang Y, et al. Reversible posttranslational modification of proteins by nitrated fatty acids in vivo. J Biol Chem. 2006; 281:20450-20463. [PubMed: 16682416] 
18. Lin D, Saleh S, Liebler DC. Reversibility of covalent electrophile-protein adducts and chemical toxicity. Chem Res Toxicol. 2008; 21:2361-2369. [PubMed: 19548357]

19. Rudolph TK, Freeman BA. Transduction of redox signaling by electrophile-protein reactions. Sci Signal. 2009; 2:re7. [PubMed: 19797270]

20. Rudolph V, Schopfer FJ, Khoo NK, Rudolph TK, Cole MP, Woodcock SR, et al. Nitro-fatty acid metabolome: saturation, desaturation, beta-oxidation, and protein adduction. J Biol Chem. 2009; 284:1461-1473. [PubMed: 19015269]

21. Reddy AT, Lakshmi SP, Dornadula S, Pinni S, Rampa DR, Reddy RC. The nitrated Fatty Acid 10nitro-oleate attenuates allergic airway disease. J Immunol. 2013; 191:2053-2063. [PubMed: 23913958]

22. Black PN, Sharpe S. Dietary fat and asthma: is there a connection? Eur Respir J. 1997; 10:6-12. [PubMed: 9032484]

23. Horrobin DF. Low prevalences of coronary heart disease (CHD), psoriasis, asthma and rheumatoid arthritis in Eskimos: are they caused by high dietary intake of EPA, a genetic variation of essential fatty acid (EFA) metabolism or a combination of both? Med Hypotheses. 1987; 22:421-428. [PubMed: 3035353]

24. Broadfield EC, McKeever TM, Whitehurst A, Lewis SA, Lawson N, Britton J, et al. A case-control study of dietary and erythrocyte membrane fatty acids in asthma. Clin Exp Allergy. 2004; 34:1232-1236. [PubMed: 15298563]

25. McKeever TM, Lewis SA, Cassano PA, Ocke M, Burney P, Britton J, et al. The relation between dietary intake of individual fatty acids, FEV1 and respiratory disease in Dutch adults. Thorax. 2008; 63:208-214. [PubMed: 17901161]

26. Kitz R, Rose MA, Schubert R, Beermann C, Kaufmann A, Bohles HJ, et al. Omega-3 polyunsaturated fatty acids and bronchial inflammation in grass pollen allergy after allergen challenge. Respir Med. 2010; 104:1793-1798. [PubMed: 20637584]

27. Kompauer I, Demmelmair H, Koletzko B, Bolte G, Linseisen J, Heinrich J. Association of fatty acids in serum phospholipids with lung function and bronchial hyperresponsiveness in adults. Eur J Epidemiol. 2008; 23:175-190. [PubMed: 18204906]

28. Emmanouil E, Manios Y, Grammatikaki E, Kondaki K, Oikonomou E, Papadopoulos N, et al. Association of nutrient intake and wheeze or asthma in a Greek pre-school population. Pediatr Allergy Immunol. 2010; 21:90-95. [PubMed: 19744220]

29. Nakamura K, Wada K, Sahashi Y, Tamai Y, Tsuji M, Watanabe K, et al. Associations of intake of antioxidant vitamins and fatty acids with asthma in pre-school children. Public Health Nutr. 2013; 16:2040-2045. [PubMed: 23021626]

30. Lumia M, Luukkainen P, Tapanainen H, Kaila M, Erkkola M, Uusitalo L, et al. Dietary fatty acid composition during pregnancy and the risk of asthma in the offspring. Pediatr Allergy Immunol. 2011; 22:827-835. [PubMed: 21929596]

31. Barros R, Moreira A, Fonseca J, Delgado L, Castel-Branco MG, Haahtela T, et al. Dietary intake of alpha-linolenic acid and low ratio of n-6:n-3 PUFA are associated with decreased exhaled NO and improved asthma control. Br J Nutr. 2011; 106:441-450. [PubMed: 21443816]

32. Standl M, Sausenthaler S, Lattka E, Koletzko S, Bauer CP, Wichmann HE, et al. FADS gene variants modulate the effect of dietary fatty acid intake on allergic diseases in children. Clin Exp Allergy. 2011; 41:1757-1766. [PubMed: 21793953]

33. Rodriguez-Rodriguez E, Perea JM, Jimenez AI, Rodriguez-Rodriguez P, Lopez-Sobaler AM, Ortega RM. Fat intake and asthma in Spanish school children. Eur J Clin Nutr. 2010; 64:10651071. [PubMed: 20664620]

34. Miyake Y, Sasaki S, Arakawa M, Tanaka K, Murakami K, Ohya Y. Fatty acid intake and asthma symptoms in Japanese children: the Ryukyus Child Health Study. Clin Exp Allergy. 2008; 38:1644-1650. [PubMed: 18702656]

35. Woods RK, Raven JM, Walters EH, Abramson MJ, Thien FC. Fatty acid levels and risk of asthma in young adults. Thorax. 2004; 59:105-110. [PubMed: 14760147]

36. Bolte G, Kompauer I, Fobker M, Cullen P, Keil U, Mutius E, et al. Fatty acids in serum cholesteryl esters in relation to asthma and lung function in children. Clin Exp Allergy. 2006; 36:293-302. [PubMed: 16499639] 
37. Li J, Xun P, Zamora D, Sood A, Liu K, Daviglus M, et al. Intakes of long-chain omega-3 (n-3) PUFAs and fish in relation to incidence of asthma among American young adults: the CARDIA study. Am J Clin Nutr. 2012; 97:173-178. [PubMed: 23193002]

38. Burns JS, Dockery DW, Neas LM, Schwartz J, Coull BA, Raizenne M, et al. Low dietary nutrient intakes and respiratory health in adolescents. Chest. 2007; 132:238-245. [PubMed: 17475634]

39. Nwaru BI, Erkkola M, Lumia M, Kronberg-Kippila C, Ahonen S, Kaila M, et al. Maternal intake of fatty acids during pregnancy and allergies in the offspring. Br J Nutr. 2012; 108:720-732. [PubMed: 22067943]

40. Schubert R, Kitz R, Beermann C, Rose MA, Lieb A, Sommerer PC, et al. Effect of n-3 polyunsaturated fatty acids in asthma after low-dose allergen challenge. Int Arch Allergy Immunol. 2009; 148:321-329. [PubMed: 19001792]

41. Mickleborough TD, Murray RL, Ionescu AA, Lindley MR. Fish oil supplementation reduces severity of exercise-induced bronchoconstriction in elite athletes. Am J Respir Crit Care Med. 2003; 168:1181-1189. [PubMed: 12904324]

42. Mickleborough TD, Lindley MR, Ionescu AA, Fly AD. Protective effect of fish oil supplementation on exercise-induced bronchoconstriction in asthma. Chest. 2006; 129:39-49. [PubMed: 16424411]

43. Almqvist C, Garden F, Xuan W, Mihrshahi S, Leeder SR, Oddy W, et al. Omega-3 and omega-6 fatty acid exposure from early life does not affect atopy and asthma at age 5 years. J Allergy Clin Immunol. 2007; 119:1438-1444. [PubMed: 17379291]

44. Moreira A, Moreira P, Delgado L, Fonseca J, Teixeira V, Padrao P, et al. Pilot study of the effects of $n-3$ polyunsaturated fatty acids on exhaled nitric oxide in patients with stable asthma. J Investig Allergol Clin Immunol. 2007; 17:309-313.

45. Hodge L, Salome CM, Hughes JM, Liu-Brennan D, Rimmer J, Allman M, et al. Effect of dietary intake of omega-3 and omega-6 fatty acids on severity of asthma in children. Eur Respir J. 1998; 11:361-365. [PubMed: 9551739]

46. Mihrshahi S, Peat JK, Marks GB, Mellis CM, Tovey ER, Webb K, et al. Eighteen-month outcomes of house dust mite avoidance and dietary fatty acid modification in the Childhood Asthma Prevention Study (CAPS). J Allergy Clin Immunol. 2003; 111:162-168. [PubMed: 12532113]

47. Covar R, Gleason M, Macomber B, Stewart L, Szefler P, Engelhardt K, et al. Impact of a novel nutritional formula on asthma control and biomarkers of allergic airway inflammation in children. Clin Exp Allergy. 2010; 40:1163-1174. [PubMed: 20545703]

48. Lundstrom SL, Yang J, Brannan JD, Haeggstrom JZ, Hammock BD, Nair P, et al. Lipid mediator serum profiles in asthmatics significantly shift following dietary supplementation with omega-3 fatty acids. Mol Nutr Food Res. 2013; 57:1378-1389. [PubMed: 23824870]

49. Emelyanov A, Fedoseev G, Krasnoschekova O, Abulimity A, Trendeleva T, Barnes PJ. Treatment of asthma with lipid extract of New Zealand green-lipped mussel: a randomised clinical trial. Eur Respir J. 2002; 20:596-600. [PubMed: 12358334]

50. Olsen SF, Osterdal ML, Salvig JD, Mortensen LM, Rytter D, Secher NJ, et al. Fish oil intake compared with olive oil intake in late pregnancy and asthma in the offspring: 16 y of registrybased follow-up from a randomized controlled trial. Am J Clin Nutr. 2008; 88:167-175. [PubMed: 18614738]

51. Woods RK, Thien FC, Abramson MJ. Dietary marine fatty acids (fish oil) for asthma in adults and children. Cochrane Database Syst Rev. 2002; (3):CD001283. [PubMed: 12137622]

52. Mickleborough TD, Lindley MR, Montgomery GS. Effect of fish oil-derived omega-3 polyunsaturated fatty acid supplementation on exercise-induced bronchoconstriction and immune function in athletes. Phys Sportsmed. 2008; 36:11-17. [PubMed: 20048468]

53. Arm JP, Horton CE, Mencia-Huerta JM, House F, Eiser NM, Clark TJ, et al. Effect of dietary supplementation with fish oil lipids on mild asthma. Thorax. 1988; 43:84-92. [PubMed: 3353893]

54. Hoyos C, Almqvist C, Garden F, Xuan W, Oddy WH, Marks GB, et al. Effect of omega 3 and omega 6 fatty acid intakes from diet and supplements on plasma fatty acid levels in the first 3 years of life. Asia Pac J Clin Nutr. 2008; 17:552-557. [PubMed: 19114389] 
55. Kremmyda LS, Vlachava M, Noakes PS, Diaper ND, Miles EA, Calder PC. Atopy risk in infants and children in relation to early exposure to fish, oily fish, or long-chain omega-3 fatty acids: a systematic review. Clin Rev Allergy Immunol. 2011; 41:36-66. [PubMed: 19997989]

56. Wood LG, Gibson PG. Dietary factors lead to innate immune activation in asthma. Pharmacol Ther. 2009; 123:37-53. [PubMed: 19375453]

57. de Vries A, Howie SE. Diet and asthma-can you change what you or your children are by changing what you eat? Pharmacol Ther. 2009; 122:78-82. [PubMed: 19248808]

58. Tricon S, Burdge GC, Kew S, Banerjee T, Russell JJ, Jones EL, et al. Opposing effects of cis-9,trans-11 and trans-10,cis-12 conjugated linoleic acid on blood lipids in healthy humans. Am J Clin Nutr. 2004; 80:614-620. [PubMed: 15321800]

59. Zulet MA, Marti A, Parra MD, Martinez JA. Inflammation and conjugated linoleic acid: mechanisms of action and implications for human health. J Physiol Biochem. 2005; 61:483-494. [PubMed: 16440602]

60. Churruca I, Fernandez-Quintela A, Portillo MP. Conjugated linoleic acid isomers: differences in metabolism and biological effects. Biofactors. 2009; 35:105-111. [PubMed: 19319853]

61. MacRedmond R, Singhera G, Attridge S, Bahzad M, Fava C, Lai Y, et al. Conjugated linoleic acid improves airway hyper-reactivity in overweight mild asthmatics. Clin Exp Allergy. 2010; 40:1071-1078. [PubMed: 20642580]

62. Macredmond R, Dorscheid DR. Conjugated linoleic acid (CLA): is it time to supplement asthma therapy? Pulm Pharmacol Ther. 2011; 24:540-548. [PubMed: 21530672] 


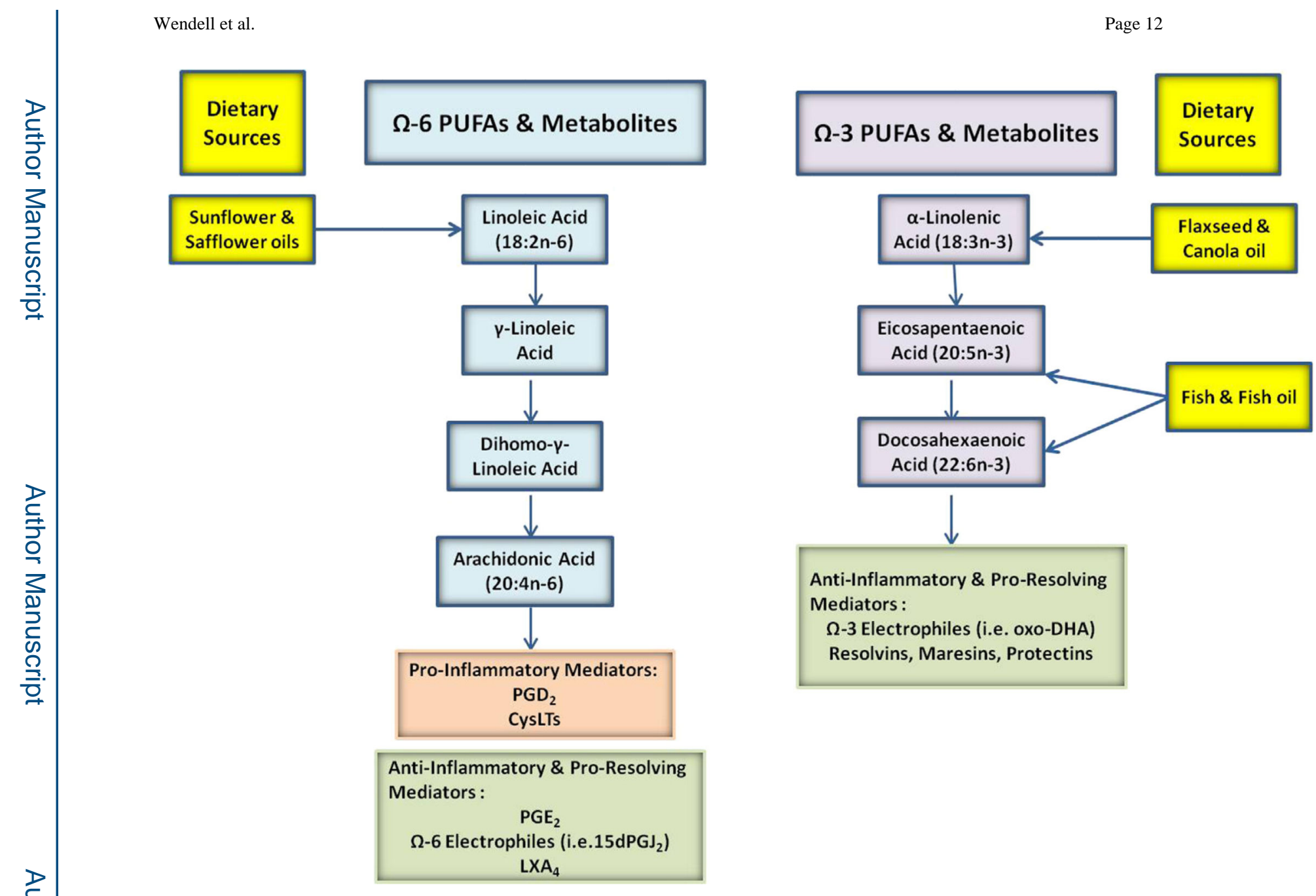

FIG 1.

Lipid mediators derived from omega-6 ( $\Omega-6)$ and omega-3 ( $\Omega-3)$ fatty acids. 


\section{TABLE I}

Observational studies on fatty acid exposure and asthma-related outcomes

\begin{tabular}{|c|c|c|c|}
\hline Study design & Study population & Outcomes & Results \\
\hline $\begin{array}{l}\text { Case-control study, United } \\
\text { Kingdom }^{24}\end{array}$ & $\begin{array}{l}89 \text { cases of asthma vs } 89 \\
\text { community matched control } \\
\text { subjects from local registries } \\
\text { (mean age } 43 \text { y) }\end{array}$ & $\begin{array}{l}\text { Fatty acid intake was determined } \\
\text { by using FFQ, and erythrocyte } \\
\text { membrane levels were } \\
\text { determined by using mass } \\
\text { spectrometry and odds of } \\
\text { asthma. }\end{array}$ & $\begin{array}{l}\mathrm{n}-3 \text { fatty acids are not protective } \\
\text { against asthma, and n- } 6 \text { fatty } \\
\text { acids are associated with lower } \\
\text { risk of asthma. }\end{array}$ \\
\hline $\begin{array}{l}\text { Cross-sectional study, The } \\
\text { Netherlands } 25\end{array}$ & 13,820 subjects (age $20-59$ y) & $\begin{array}{l}\text { Fatty acid intake was determined } \\
\text { by using FFQ. Lung function } \\
\text { was determined by using } \\
\text { spirometry (FEV } 1 \text { and FVC). A } \\
\text { respiratory symptom } \\
\text { questionnaire was used regarding } \\
\text { reported wheeze, asthma, and } \\
\text { COPD symptoms. }\end{array}$ & $\begin{array}{l}\mathrm{n}-3 \text { intake is not protective } \\
\text { against COPD or asthma. High } \\
\text { n-6 intake is associated with } \\
\text { FEV } \text { decrease, notably in }_{\text {smokers. }}\end{array}$ \\
\hline Case-control study, Germany ${ }^{26}$ & $\begin{array}{l}38 \text { asthmatic patients with grass } \\
\text { pollen allergy vs } 19 \text { age-matched } \\
\text { healthy control subjects (age } 18- \\
45 \mathrm{y} \text { ) }\end{array}$ & $\begin{array}{l}\text { Lung function was measured by } \\
\text { using spirometry, and bronchial } \\
\text { hyperresponsiveness was } \\
\text { measured using methacholine } \\
\text { testing, allergen inhalation } \\
\text { challenge, and measurement of } \\
\text { exhaled NO. Stratification was } \\
\text { according to low (Q25) and high } \\
\text { (Q75) ratios of n-3 to n-6. }\end{array}$ & $\begin{array}{l}\text { PUFA ratios (n-3/n-6) were less } \\
\text { in asthmatic patients, and higher } \\
\text { exhaled NO levels were present } \\
\text { in Q25 asthmatic patients (or } \\
\text { lower n-3/n-6 ratio group) } \\
\text { compared with Q75 patients } \\
\text { after bronchial inflammation. } \\
\text { There was a trend toward higher } \\
\text { bronchial hyperreactivity in } \\
\text { Q25, as indicated by greater } \\
\text { change in FEV }\end{array}$ \\
\hline Cross-sectional study, Germany ${ }^{27}$ & $\begin{array}{l}593 \text { adults (age } 20-64 \text { y) } \\
\text { sampled from a respiratory } \\
\text { health survey }\end{array}$ & $\begin{array}{l}\text { Fatty acid intake and metabolism } \\
\text { were measured by using 3-d } \\
\text { dietary survey and serum } \\
\text { phospholipid extraction and } \\
\text { evaluation. Lung function was } \\
\text { measured by using FEV } \text { Fnd }_{1} \text { and } \\
\text { FVC, and bronchial } \\
\text { hyperresponsiveness was } \\
\text { measured by using methacholine } \\
\text { challenge. }\end{array}$ & $\begin{array}{l}\mathrm{n}-3 \text { (DHA) was associated with } \\
\text { improved lung function in men } \\
\text { but not women. n- } 6 \text { (dihomo- } \gamma- \\
\text { linolenic acid) and } \\
\text { monosaturated fatty acid } \\
\text { (palmitoleic acid) were } \\
\text { negatively associated with lung } \\
\text { function in men but not women. }\end{array}$ \\
\hline Cross-sectional study, Greece ${ }^{28}$ & $\begin{array}{l}1964 \text { preschool children (age } 24- \\
72 \text { mo) from nurseries and day } \\
\text { care centers }\end{array}$ & $\begin{array}{l}\text { Three-day dietary was intake } \\
\text { measured by using a home } \\
\text { parental dietary intake record, } \\
\text { and asthma outcomes were } \\
\text { measured by using the ISAAC } \\
\text { questionnaire. }\end{array}$ & $\begin{array}{l}\text { Monosaturated fatty acid intake } \\
\text { was associated with increased } \\
\text { risk of asthma symptoms. } \\
\text { Magnesium intake was } \\
\text { associated with increased } \\
\text { wheeze, whereas vitamin C and } \\
\text { calcium appeared to be } \\
\text { protective. }\end{array}$ \\
\hline Cross-sectional study, Japan ${ }^{29}$ & $\begin{array}{l}452 \text { children (age } 3-6 \text { y), } \\
\text { including asthmatic and } \\
\text { nonasthmatic patients }\end{array}$ & $\begin{array}{l}\text { Three-day dietary intake was } \\
\text { measured by using a home-based } \\
\text { parental dietary intake record. } \\
\text { Asthma case status was } \\
\text { ascertained by means of } \\
\text { questionnaire. }\end{array}$ & $\begin{array}{l}\text { There was no association } \\
\text { between asthma diagnosis and } \\
\text { any type of fatty acid intake, but } \\
\text { there was a significant } \\
\text { association with low intake of } \\
\text { vitamins C and E. }\end{array}$ \\
\hline Cross-sectional study, Finland ${ }^{30}$ & $\begin{array}{l}2679 \text { children from } 3 \text { university } \\
\text { hospitals from the Finnish Type } \\
1 \text { Diabetes Prediction and } \\
\text { Prevention (DIPP) nutrition } \\
\text { study }\end{array}$ & $\begin{array}{l}\text { Dietary intake was measured } \\
\text { during the } 8 \text { th month of } \\
\text { pregnancy by using FFQ. } \\
\text { Asthma risk was assessed at } 5 \mathrm{y} \text {, } \\
\text { as determined by using the } \\
\text { ISAAC questionnaire. }\end{array}$ & $\begin{array}{l}\text { Low intake of a-linolenic acid } \\
\text { and total PUFAs during } \\
\text { pregnancy was associated with } \\
\text { increased risk of asthma in } \\
\text { offspring, whereas low intake of } \\
\text { AA and high intake of saturated } \\
\text { fatty acids (palmitic acid) was } \\
\text { associated with decreased risk } \\
\text { of asthma in offspring at } 5 \mathrm{y} \text {. }\end{array}$ \\
\hline Cross-sectional study, Portugal ${ }^{31}$ & $\begin{array}{l}174 \text { asthmatic patients (adults } \\
\text { age }>16 \mathrm{y} \text { ), outpatient clinics }\end{array}$ & $\begin{array}{l}\text { Dietary intake over previous } 12 \\
\text { mo was measured by using FFQ } \\
\text { and asthma control based on a } \\
\text { combination of lung function } \\
\left(\mathrm{FEV}_{1}\right) \text {, exhaled NO levels, }\end{array}$ & $\begin{array}{l}\text { High n- } 6 / n-3 \text { ratio predicted } \\
\text { higher exhaled NO levels, } \\
\text { whereas high n- } 3 \text {, a-linolenic } \\
\text { acid, and saturated fatty acid } \\
\text { levels were associated with }\end{array}$ \\
\hline
\end{tabular}




\begin{tabular}{lll}
\hline Study design & Study population & Outcomes \\
\hline & & $\begin{array}{l}\text { Asthma Control Questionnaire } \\
\text { (ACQ) scores, and asthma } \\
\text { quality of life (ALQ) test results. }\end{array}$ \\
& \\
& & \\
Cross-sectional study, Germany ${ }^{32}$ & $\begin{array}{ll}2000 \text { children (age 10 y) from 2 } \\
\text { prospective birth cohort studies }\end{array}$ & $\begin{array}{l}\text { Fatty acid intake was measured } \\
\text { by using FFQ, and atopic disease } \\
\text { was measured by using specific } \\
\text { serum IgE concentrations with } \\
\text { stratification by FADS1 FADS2 } \\
\text { genotype. }\end{array}$ \\
& & \\
& &
\end{tabular}

Cross-sectional study, Spain ${ }^{33}$ 638 Spanish schoolchildren (age $8-13$ y)

\author{
Cross-sectional study, Japan ${ }^{34}$
}

25,033 children (age 6-15 y) using data from the Ryukyus Child Health Study (RYUCHS)

Cross-sectional study, Australia ${ }^{35}$

1,601 adults with and without known asthma (age 20-44 y)

526 children (age 8-11 y) from

Nested case-control study,

Nested case-co
Germany

Longitudinal analysis ${ }^{37}$
Prevalence of current asthma was measured by using a parental questionnaire. Intake of lipids, fatty acids, and lipid-rich foods in a 3-d period was measured by using parental dietary record.

Symptoms of asthma were defined based on diagnostic criteria from ISAAC, and dietary intake was measured by using food questionnaires for children over a 1-mo period.

Dietary intake was measured by using FFQ. Asthma and atopy were measured based on respiratory questionnaire results, skin prick test results, lung function $\left(\mathrm{FEV}_{1}\right)$, and methacholine challenge results for bronchial

hyperresponsiveness and plasma fatty acid levels.

Plasma fatty acid levels were measured. Asthma Symptoms or diagnosis were determined based on respiratory questionnaires completed by parents. Atopy was measured by using skin prick tests, and bronchial hyperresponsiveness was measured after hypertonic saline challenge.

Diet was assessed by using FFQ at 3 time points in a $20-y$ period. Incidents of self-reported asthma were determined based on a physician's diagnosis and/or use of asthma medications.

\section{Results}

lower exhaled NO levels.

Higher intake of n-3 was associated with better controlled asthma. There was no association between antioxidant vitamins and minerals and controlled asthma.

There was no associations between those with atopic disease or allergic sensitization and FADS genotype or fatty acid intake. Higher margarine intake was associated with risk of asthma in homozygotes for the major allele.

Energy from lipids, saturated fatty acids, and myristic and palmitic acids was significantly associated with current asthma, as well as butter intake. There was no association between asthma and intake of any other fatty acids, n- $6 / \mathrm{n}-3$ ratio, or consumption of margarine, milk products, fish, meat, eggs, or vegetable oils.

Intake of n-3 and n-6 fatty acids and linolenic acid was significantly associated with increased prevalence of wheeze. There was no association between consumption of a-LA EPA, DHA, AA, or $\mathrm{n}-3 / \mathrm{n}-6$ ratio with the prevalence of wheeze. Total fat, saturated fatty acids, and monounsaturated fatty acids were not related to wheeze.

There was no association between any plasma fatty acid levels and atopy or asthma, except dihomo cLA, an n-6 fatty acid, which was positively associated with asthma diagnosis.

EPA levels were not associated with asthma or lung function, whereas linolenic levels were associated (both with $\mathrm{n}-3$ fatty acids). There was a strong association between AA and asthma (n-6 fatty acid) with $\mathrm{FEV}_{1}$ decreases. LA was negatively associated with current asthma and an incremental change in $\mathrm{FEV}_{1}$. The n-6/n-3 ratio, palmitic acid, and OA had no association with asthma or lung function.

Four hundred forty-six cases of incident asthma were identified in a 20-y follow-up, and n-3 fatty acid intake was inversely associated with incident asthma. 


\begin{tabular}{|c|c|c|c|}
\hline Study design & Study population & Outcomes & Results \\
\hline $\begin{array}{l}\text { Cross-sectional study, United } \\
\text { States and Canada }\end{array}$ & 2,112 twelfth-grade students & $\begin{array}{l}\text { Lung function was determined } \\
\text { by using a respiratory } \\
\text { questionnaire. Dietary intake of } \\
\text { antioxidants, micronutrients, } \\
\text { retinol, and fatty acids were } \\
\text { measured. }\end{array}$ & $\begin{array}{l}\text { Low dietary fruit intake and n-3 } \\
\text { fatty acid intake were associated } \\
\text { with increased odds of } \\
\text { respiratory symptoms (chronic } \\
\text { bronchitis, wheeze, and asthma) } \\
\text { Lower vitamin C intake was } \\
\text { seen in smokers, and they had } \\
\text { higher ORs for respiratory } \\
\text { symptoms. }\end{array}$ \\
\hline Cross-sectional study, Finland ${ }^{39}$ & $\begin{array}{l}2441 \text { children (age } 5 \text { y) } \\
\text { participating in a diabetes } \\
\text { mellitus type } 1 \text { study cohort }\end{array}$ & $\begin{array}{l}\text { Dietary intake of fats in the } 8 \text { th } \\
\text { month of pregnancy was } \\
\text { determined by using FFQ. A } \\
\text { parental record of allergic } \\
\text { disease was determined by using } \\
\text { the ISACC questionnaire in } \\
\text { offspring at } 5 \mathrm{y} \text {. }\end{array}$ & $\begin{array}{l}\text { Higher intake of total PUFAs } \\
\text { and a-linolenic fatty acid was } \\
\text { weakly associated with a } \\
\text { nonsignificantly lower risk of } \\
\text { allergic rhinitis }\end{array}$ \\
\hline
\end{tabular}

$C O P D$, Chronic obstructive pulmonary disease; $E I B$, exercise-induced bronchospasm; $F A D S$, fatty acid desaturase; $F F Q$, food frequency questionnaire; $F V C$, forced vital capacity; ISAAC, International Study of Asthma and Allergies in Childhood; $O R$, odds ratio. 


\section{TABLE II}

\section{Clinical trials of fatty acid supplementation and asthma}

\begin{tabular}{|c|c|c|}
\hline Study design & Study population & Treatment \\
\hline $\begin{array}{l}\text { Randomized, double-blind, } \\
\text { placebo-controlled trial, Portugal }^{44}\end{array}$ & $\begin{array}{l}20 \text { female patients } \\
\text { with stable persistent } \\
\text { asthma }\end{array}$ & $\begin{array}{l}\text { DHA and EPA } \\
\text { combination plus } 10 \\
\text { mg of vitamin E or } \\
\text { placebo twice daily for } \\
2 \mathrm{wk}\end{array}$ \\
\hline $\begin{array}{l}\text { Observational cohort analysis of } \\
\text { randomized controlled trials, } \\
\text { Australia }^{43}\end{array}$ & $\begin{array}{l}516 \text { children (age } 18 \\
\text { mo- } 5 \text { y) with a } \\
\text { family history of } \\
\text { asthma }\end{array}$ & $\begin{array}{l}\text { Fish oil supplement } \\
(500 \mathrm{mg} \text { of tuna fish } \\
\text { oil) or placebo }(500 \mathrm{mg} \\
\text { of Sunola oil) }\end{array}$ \\
\hline
\end{tabular}

Outcomes
FENO was determined,
with ACQ scores and
FEV $_{1}$ as secondary
outcomes.

\section{Results}

Short-term dietary supplementation with n-3 PUFAs was not associated with changes in exhaled NO levels, asthma control, or lung function in women with stable asthma.

Symptoms or diagnoses of asthma and allergic disease were determined at $18 \mathrm{mo}, 3 \mathrm{y}$, and $5 \mathrm{y}$.
Double-blind, randomized controlled trial, Australia ${ }^{45}$

Parallel double-blind, randomized trial, Germany ${ }^{40}$
39 asthmatic children (age 8-12 y) with a history of wheeze in the last 12 mo and AHR to histamine

23 asthmatic patients with dust mite allergy (age 22-29 y)
Fish oil (n-3 group, $\mathrm{n}=$ 20) or safflower/palm/ olive oil (n-6 group, n $=19$ ) supplements for 6 mo

PUFA-enriched blend (450 mg of EPA, 180 $\mathrm{mg}$ of, $60 \mathrm{mg}$ of $\gamma$-LA, and $60 \mathrm{mg}$ of stearidonic acid) or placebo
Randomized controlled trial, Australia $^{46}$

Randomized, double-blind, placebo-controlled trial, Denver, Colorado $^{47}$
616 pregnant women whose unborn children were at high risk of asthma based on family history

43 children (age 614 y) with mild-tomoderate persistent asthma
HDM avoidance intervention; dietary supplementation with daily n-3-rich tuna fish oil $(500 \mathrm{mg})$, margarines, and cooking oils or placebo (Sunola oil) starting at $6 \mathrm{mo}$

Enriched n-3 fatty acid and antioxidant $(3 \mathrm{~g}$ of EPA, $1.6 \mathrm{~g}$ of DHA, $3.0 \mathrm{~g}$ of GLA; vitamins $\mathrm{E}$ and $\mathrm{C}, \beta$-carotene, taurine, zinc, copper, selenium, molybdenum, and calcium) formula vs control (same caloric amount blended with $100 \%$ high-oleic safflower oil) formula for 12-wk trial as between meal snack or at mealtime
Lung function and bronchial hyperresponsiveness were determined by using $\mathrm{FEV}_{1}, \mathrm{FVC}$, and histamine inhalation. LPS stimulated PBMC TNF-a production.

Three weeks of dietary supplementation and then daily challenge with low dose mite allergen was done for $2 \mathrm{wk}$ after which subjects. Lung function was measured based on $\mathrm{FEV}_{1}$ and exhaled NO levels. Sputum and plasma eosinophil counts and CysLT levels were measured after allergen exposure.

Asthma symptoms or diagnosis or treatment were assessed by using a parental questionnaire, atopic status was determined by using skin prick testing, and serum IgE levels in offspring were measured at $18 \mathrm{mo}$.

Numbers of asthma-free days were determined, and assessment of fatty acid levels and safety outcomes was performed.

Measurement of asthmatic symptoms, skin prick test responses, serum eosinophilic cationic protein levels, eosinophil counts, serum IgE levels, exhaled NO levels, and methacholine challenge test results were determined.
There was no association between plasma levels of n-3 or $\mathrm{n}-6$ at $18 \mathrm{mo}, 3 \mathrm{y}$, and $5 \mathrm{y}$ and the prevalence of asthma or wheezing, eczema, or atopy at $5 \mathrm{y}$.

TNF level decrease in the $\mathrm{n}-3$ group trended toward significance. Diet had no effect on the severity of asthma in children or other outcome measures.

Exhaled NO levels were lower in the n-3 PUFA group before and after allergen challenge compared with the placebo group. Serum eosinophil counts, eosinophilic cationic protein levels, and in vitro CysLT release are decreased in the n-3 PUFA group.

There was a lower prevalence of wheeze in the diet intervention group, but physiciandiagnosed asthma was not reduced. HDM reduction reduced use of oral steroids but did not affect outcomes.

There were no differences in asthmafree days between the 2 groups. Higher exhaled NO levels were seen in the control group compared with the treatment group at 4 , 8, and 12 wk. Higher EPA levels were found in serum and PBMC phospholipids in the treatment group. No differences were found in adverse events. 


\begin{tabular}{|c|c|c|c|c|}
\hline Study design & Study population & Treatment & Outcomes & Results \\
\hline $\begin{array}{l}\text { Randomized, double-blind } \\
\text { crossover study, United } \\
\text { Kingdom }^{41}\end{array}$ & $\begin{array}{l}20 \text { subjects, } \\
\text { including } 10 \text { with } \\
\text { clinically diagnosed } \\
\text { EIB and } 10 \text { healthy } \\
\text { control subjects } \\
\text { recruited from } \\
\text { university and } \\
\text { sporting teams }\end{array}$ & $\begin{array}{l}\text { Supplemental fish oil } \\
\text { ( } 3.2 \mathrm{~g} \text { of EPA and } 2.2 \mathrm{~g} \\
\text { of DHA) or placebo } \\
\text { (olive oil) for } 3 \mathrm{wk}, \\
\text { washout period (normal } \\
\text { diet) for } 2 \mathrm{wk} \text {, and then } \\
\text { alternative supplement } \\
\text { for } 3 \mathrm{wk}\end{array}$ & $\begin{array}{l}\text { At all } 3 \text { phases, plasma } \\
\text { LTB }_{4} \text {, TNF-a, IL-1 } \beta \text {, and } \\
\text { urinary LTE } \text { and } 9 a \\
\text { levels, as well as } 11 \beta- \\
\text { PGF }_{2} \text { levels, were } \\
\text { measured before and after } \\
\text { exercise. Lung function } \\
\text { was measured by using } \\
\text { FEV }_{1} \text { after exercise and } \\
\text { sputum inflammatory } \\
\text { mediators. }\end{array}$ & $\begin{array}{l}\text { There was less of a } \\
\text { decrement in lung } \\
\text { function after exercise } \\
\text { and decreased } \\
\text { inflammatory mediator } \\
\text { levels in the n-3 PUFA } \\
\text { diet group. }\end{array}$ \\
\hline $\begin{array}{l}\text { Double-blind crossover study, } \\
\text { Sweden }{ }^{48}\end{array}$ & $\begin{array}{l}25 \text { patients with } \\
\text { mild-to-moderate } \\
\text { asthma (20-54 y) }\end{array}$ & $\begin{array}{l}3 \mathrm{wk} n-3 \text { fatty acid } \\
\text { supplement (daily dose: } \\
4 \mathrm{~g} \text { of EPA and } 2 \mathrm{~g} \text { of } \\
\text { DHA) or placebo } \\
\text { (50:50 mix of soybean } \\
\text { and corn oil), followed } \\
\text { by washout period } \\
\text { (normal diet) for } 3 \mathrm{wk} \\
\text { and then switch to } \\
\text { alternative therapy for } \\
3 \mathrm{wk}\end{array}$ & $\begin{array}{l}\text { Fatty acid composition of } \\
\text { serum phospholipids at } \\
\text { baseline and after each } \\
\text { period of treatment was } \\
\text { measured. }\end{array}$ & $\begin{array}{l}\mathrm{n}-3 \text { diet } \\
\text { supplementation alters } \\
\text { PUFA ratio and the } \\
\text { ratio of downstream } \\
\text { oxylipins. }\end{array}$ \\
\hline $\begin{array}{l}\text { Randomized, double-blind, } \\
\text { crossover study, United } \\
\text { Kingdom }^{42}\end{array}$ & $\begin{array}{l}16 \text { patients with } \\
\text { mild-to-moderate } \\
\text { persistent asthma } \\
\text { with EIB }\end{array}$ & $\begin{array}{l}\mathrm{n}-3 \text { PUFAs ( } 3.2 \mathrm{~g} \text { of } \\
\text { EPA and } 2.0 \mathrm{~g} \text { of } \\
\text { DHA) or placebo (olive } \\
\text { oil) over } 8 \mathrm{wk}(1 \mathrm{wk} \text { on } \\
\text { normal diet, } 3 \mathrm{wk} \text { on } \\
\text { treatment diet or } \\
\text { placebo, } 2 \text {-wk washout } \\
\text { period, and then } \\
\text { switched to alternative } \\
\text { diet for } 2 \mathrm{wk} \text { ) }\end{array}$ & $\begin{array}{l}\text { Pre-exercise and } \\
\text { postexercise } \\
\text { measurements of } \\
\text { pulmonary function, } \\
\text { induced sputum cell count } \\
\text { differential, } \\
\text { proinflammatory } \\
\text { eicosanoid metabolite and } \\
\text { cytokine concentrations, } \\
\text { and eicosanoid metabolites } \\
\mathrm{LTB}_{4} \text { and } \mathrm{LTB}_{5} \text { were } \\
\text { measured from activated } \\
\text { PMNLs. }\end{array}$ & $\begin{array}{l}\text { Fish oil diet improved } \\
\text { pulmonary function } \\
\text { and reduced sputum } \\
\text { proinflammatory } \\
\text { mediators compared } \\
\text { with placebo and } \\
\text { normal diets. }\end{array}$ \\
\hline $\begin{array}{l}\text { Randomized, double-blind, } \\
\text { placebo-controlled trial, Russia }{ }^{49}\end{array}$ & $\begin{array}{l}46 \text { patients with } \\
\text { mild-to-moderate } \\
\text { atopic asthma (age } \\
18-56 \text { y) }\end{array}$ & $\begin{array}{l}\text { Four capsules of lipid } \\
\text { extract ( } 50 \mathrm{mg} \text { of n-3 } \\
\text { PUFAs, including } \\
\text { DHA and EPA, and } \\
100 \mathrm{mg} \text { of olive oil) or } \\
\text { placebo ( } 150 \mathrm{mg} \text { of } \\
\text { olive oil) for } 8 \mathrm{wk}\end{array}$ & $\begin{array}{l}\text { Patient-recorded } \\
\text { symptoms and medication } \\
\text { use before study } \\
\text { medication doses were } \\
\text { determined. } \mathrm{FEV}_{1} \text { was } \\
\text { measured by using } \\
\text { spirometry and } \\
\text { concentration of exhaled } \\
\mathrm{H}_{2} \mathrm{O}_{2} \text {. }\end{array}$ & $\begin{array}{l}\text { Decreased daytime } \\
\text { wheeze and exhaled } \\
\mathrm{H}_{2} \mathrm{O}_{2} \text { levels and } \\
\text { increased morning } \\
\mathrm{PEF} \text { were seen in the } \\
\text { lipid extract group. }\end{array}$ \\
\hline Cross-sectional study, Denmark ${ }^{50}$ & $\begin{array}{l}528 \text { children (age } 16 \\
\text { y) identified in } \\
\text { registries from } \\
\text { previous study in } \\
1990 \text { whose mothers } \\
\text { had fish oil } \\
\text { supplementation or } \\
\text { placebo during the } \\
\text { last } 6 \text { wk of } \\
\text { pregnancy }\end{array}$ & $\begin{array}{l}\text { Fish oil } \\
\text { supplementation with } \\
\text { four 1-g gelatin } \\
\text { capsules (32\% EPA, } \\
23 \% \text { DHA, and } 2 \mathrm{mg} \text { of } \\
\text { tocopherol) or four 1-g } \\
\text { capsules of olive oil } \\
\text { (control 1) or no } \\
\text { supplement (control 2) } \\
\text { from week } 30 \text { of } \\
\text { pregnancy until } \\
\text { delivery }\end{array}$ & $\begin{array}{l}\text { Asthma diagnosis was } \\
\text { determined in offspring at } \\
16 \text { y of age. Follow-up } \\
\text { was extracted from the } \\
\text { national patient registry. }\end{array}$ & $\begin{array}{l}\text { Supplementation with } \\
\text { n-3 PUFAs during late } \\
\text { pregnancy reduced the } \\
\text { risk of asthma and } \\
\text { allergic asthma in } \\
\text { offspring. }\end{array}$ \\
\hline
\end{tabular}

$A C Q$, Asthma Control Questionnaire; $C y s L T$, cysteinyl leukotriene; $E I B$, exercise-induced bronchospasm; $F E N O$, fraction of exhaled nitric oxide; $F F Q$, food frequency questionnaire; $F V C$, forced vital capacity; $H D M$, house dust mite; $N O$, nitric oxide; $P E F$, peak expiratory flow; $P M N L$, peripheral mononuclear lymphocytes. 